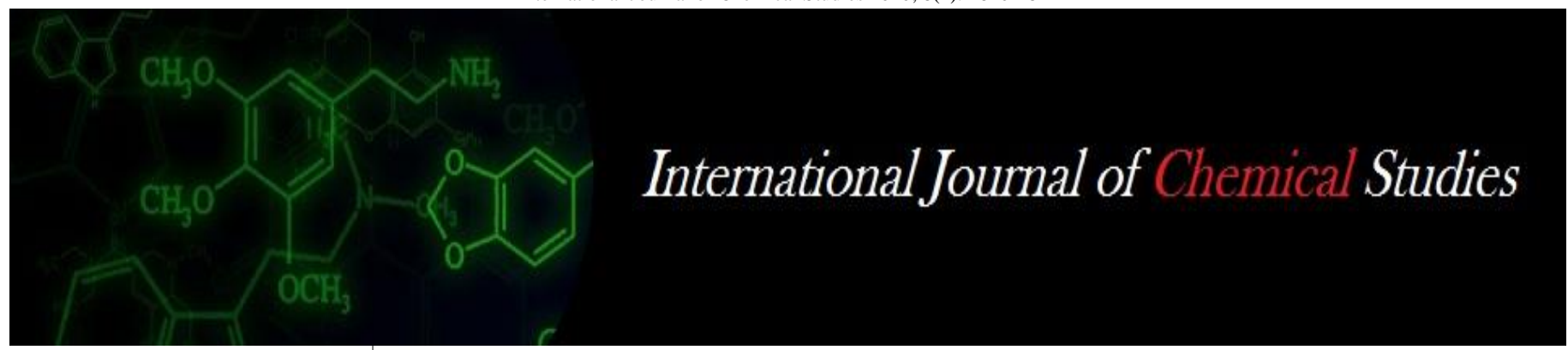

P-ISSN: 2349-8528

E-ISSN: 2321-4902

www.chemijournal.com

IJCS 2020; 8(1): 2820-2824

(C) 2020 IJCS

Received: 04-11-2019

Accepted: 06-12-2019

\section{Kuldeep Kumar}

Department of Plant Pathology,

C. S. Azad University of

Agriculture and Technology,

Kanpur, Uttar Pradesh, India

\section{SK Biswas}

Department of Plant Pathology,

C. S. Azad University of

Agriculture and Technology,

Kanpur, Uttar Pradesh, India

\section{Arshad Husain}

Department of Plant Pathology,

C. S. Azad University of

Agriculture and Technology,

Kanpur, Uttar Pradesh, India

\section{Shivam Kumar}

Department of Plant Pathology,

C. S. Azad University of

Agriculture and Technology,

Kanpur, Uttar Pradesh, India

Corresponding Author:

Kuldeep Kumar

Department of Plant Pathology,

C. S. Azad University of

Agriculture and Technology,

Kanpur, Uttar Pradesh, India

\section{Physical parameters of casing materials on yield parameter of white button mushroom [Agaricus bisporus (longe. Imboch)]}

\author{
Kuldeep Kumar, SK Biswas, Arshad Husain and Shivam Kumar
}

DOI: https://doi.org/10.22271/chemi.2020.v8.i1aq.8695

\begin{abstract}
Combinations of different casing mixture showed significant variation in water holding capacity with the maximum (95.95 per cent) in $\mathrm{T}_{7}$ treatment $(\mathrm{FYM}+$ Soil + Sand (2:1:1). Similarly, different casing mixture showed significant variation on bulk density varies from $37.75-65.40$ per cent. The casing materials have ability to increase yield and yield parameters like length and diameter of stalk, thickness of pileus etc. of white button mushroom. The maximum length and diameter of stalk was found in $\mathrm{T}_{7}-$ FYM + Soil + Sand (2:1:1), representing $3.04 \mathrm{~cm}$ and $2.84 \mathrm{~cm}$., respectively. The significant variation on diameter and thickness of pileus $(\mathrm{cm})$ was also found maximum in $\mathrm{T}_{7}-\mathrm{FYM}+$ Soil + Sand (2:1:1), representing $5.49 \mathrm{~cm}$ and $1.89 \mathrm{~cm}$. against 4.01 and $1.14 \mathrm{~cm}$.in case of control. The casing materials have ability to increase the fresh and dry matter on fruiting body of mushroom with maximum in $\mathrm{T}_{7}-\mathrm{FYM}+$ Soil + Sand (2:1:1), representing 1192.41 and $173.42 \mathrm{~g}$, against $763.89 \mathrm{~g}$ and $82.8(\mathrm{~g})$ in case of control.
\end{abstract}

Keywords: Physical, casing materials, yield parameter, white button mushroom, Agaricus bisporus

\section{Introduction}

Commercial production of edible mushrooms represents unique exploitation of the microbial technology for bioconversion of the agricultural, industrial, forestry and house- hold wastes into nutritious food. Indoor cultivation of mushrooms and utilizing the vertical space is regarded as the highest protein producer per unit area and time, almost hundred times more than the conventional agriculture and animal husbandry. Protein contents vary between 24 to 44\% in Agaricus sp. The protein value of mushrooms is twice as that of asparagus and potato, four times as that of tomato and carrots, and six times as that of oranges. Their energy value also varies according to species, which is about equal to that of an apple (Adejumo and Awosanya, 2005) ${ }^{[1]}$. This hi-tech horticulture venture has a promising scope to meet the food shortages. It is gaining importance in recent years due to increasing global demand for protein. These are considered as source of protein, vitamins, fat, carbohydrates, amino acids and minerals. All essential amino acids are present as well as water-soluble vitamins. These are good sources of vitamins like riboflavin, biotin and thiamine, indicated that mushroom is about $16.5 \%$ dry matter out of which $7.4 \%$ is crude fiber, $14.6 \%$ is crude protein and $4.48 \%$ is fat and oil. The mushroom cultivation uses agro-waste efficiently and converts it into quality food, imparts environmental sustainability and helps in socio-economic upliftment of the common people. It is prepared from a mixture of organic materials subjected to a composting process for making it selective for growth of $A$. bisporus. Casing soil plays an important role in the cultivation of $A$. bisporus. Although many different materials may adequately function as a casing layer, peat is generally used and recommended as a good casing medium. This is because of its unique water holding and structural properties makes it widely accepted as ideal for the purposes of casing (Colak et al., 2007) ${ }^{[6]}$. In the commercial cultivation of mushrooms, compost colonized with mushroom mycelium is covered with a $3-5 \mathrm{~cm}$ thick casing layer to initiate the development of sporophores. The main function of casing layer is the production of mushrooms in quantity. Casing layer, which is nutritionally deficient medium brings about important morphological changes from transition of vegetative growth to fruiting stage. Casing is generally done to make a surface where uniform fruitification can take place and to provide anchorage and essential reserves for developing sporophores of mushrooms (Shandilya, 
2002). The aim of this study was to evaluate the effect of different casing materials on physical, growth parameters and yield of white button mushroom.

\section{Material and Method \\ Collection of materials}

Wheat straw was used of the studies as the base material. They were procured from the Kanpur market from the respective current year's harvest wheat straw used was $5-8 \mathrm{~cm}$ in length was used for compost preparation. Wheat grains were procured from local market. FYM manure was procured from the Dairy Farm at CSAUA\&T Kanpur. Similarly, chemicals and other fertilizers were procured from a local dealer of Kanpur

\section{Procedure for compost preparation}

Compost by this method was prepared on a cemented platform which was thoroughly washed $24 \mathrm{~h}$ before composting operation began. Other ingredients viz; wheat bran, urea DAP MoP, gypsum etc. were added to straw etc. were made into a heap and little quantity of water added so that these materials become moist. Later on this heap was covered with a gunny bag. On the following day wheat/paddy straw was thoroughly mixed with the ingredients and a pile measuring 5'x5'x length was made. More water was added to the pile if required. It was kept as such for 5 days. Temperature of the pile was constantly monitored with the help of stem thermometers. On 6th day first turning was given to the pile. Turning was given in such a manner that each and every portion got equal opportunity for aeration. Similarly, other turnings were given on 10th, 13th (gypsum added), 16th, 19th, 22nd, and 25th day. On 28th day compost was break opened, if no ammonia smell persisted then it was spawned and filled in polythene bags or in trays. If ammonia smell persisted, additional turning was given to the pile.

\section{Cultivation}

Fresh polythene bags were taken for conducting experiment in bags. Each polybag was filled with $4 \mathrm{Kg}$ of compost. The bag was through spawning with freshly prepared spawn @ 2.5\% through surface method system. The bags were then covered with newspaper sheets pre-sterilized with $0.5 \%$ formaldehyde solution and were later kept wet by sprinkling water regularly. The bags were kept for spawn running at $24 \pm 1 \mathrm{C}$ for $12-15$ days or at lower temperature for more duration.

\section{Casing}

It was steam sterilized at $65^{\circ} \mathrm{C}$ for $4^{\text {th }} \cdot \mathrm{pH}$ of the casing material was kept between 7.2-7.4. It was applied over fully spawn-run compost uniformly ( $4 \mathrm{~cm}$ thick). Care was taken to keep the casing layer moist by spraying water regularly. Twothree years old farm yard manure and garden soil (1:1) was used as the casing mixture. Four test casing materials viz., farm yard manure (2-3 year old farm yard manure) (FYM), burnt rice husk (Ash), garden soil and sand were used to prepare casing mixture as describe below on below.

\section{Experimental Details}

- Number of treatments- 10

- Genotypes of Agaricus spp.

- Number of replication - 3

- Substrate- Wheat straw compost

- Quantity of compost per bag - $4 \mathrm{~kg}$ per bag

- Rate of spawning - 1-2 kg per quintal/ compost.

- Design - CRD.
Treatment Details

$\mathrm{T}_{1}-\mathrm{FYM}+$ Soil $(2: 1)$

$\mathrm{T}_{2}-\mathrm{FYM}+$ Soil $(1: 1)$

$\mathrm{T}_{3}-\mathrm{FYM}+$ Sand $(2: 1)$

$\mathrm{T}_{4}-\mathrm{FYM}+$ Sand $(1: 1)$

$\mathrm{T}_{5}-\mathrm{FYM}+$ Soil + Ash $(2: 1: 1)$

$\mathrm{T}_{6}-\mathrm{FYM}+$ Sand +Ash $(2: 1: 1)$

$\mathrm{T}_{7}-\mathrm{FYM}+$ Soil + Sand $(2: 1: 1)$

$\mathrm{T}_{8}-\mathrm{FYM}+$ Ash $(3: 1)$

$\mathrm{T}_{9}$ - FYM +Sand+ Ash $(3: 1: 1 / 2)$

$\mathrm{T}_{10}$ - FYM (Control)

\section{Cropping room}

It was effective in well ventilated rooms which were fumigated with $2 \%$ formaldehyde before use. Desired humidity in the rooms was maintained by humidifier or by sprinkling water on floors or walls. Temperature of the growing room ranged between $12-18 \mathrm{C}$ during cropping. During December and January months artificial heating was done by heaters/hot air blowers to maintain the temperature at the optimum range. The observation were taken on the following parameters.

\section{Observations recorded \\ i. Length of stalk \\ ii. Diameter of stalk \\ iii. Diameter of pileus \\ iv. Thickness of pileus \\ v. Dry weight and fresh weight}

\section{Determination of physical parameters}

The physical parameters included particle density, bulk density, porosity and water holding capacity of different casing materials were determine as per following methods.

\section{Bulk density}

Bulk density was studied by core method (Singh, 1980). A large weighing bottle of about $50 \mathrm{ml}$ capacity was weighed without stopper. It was filled with casing material and flushed up to the brim by tapping the bottle about 20 times and weighed again. Then the casing material was removed and bottle was filled with water by means of graduated pipette in order to note the exact volume of water needed to fill the bottlle. Thereafter, the bulk was calculated by the following formula:

Bulk density = -------------- $\mathrm{g} / \mathrm{cm}^{3}$

Where,

$\mathrm{W}_{1}=$ Weight of empty bottle

$\mathrm{W}_{2}=$ Weight of bottle and casing mixture

$\mathrm{V}=$ Volume of soil

\section{Results and Discussion}

Effect of different combination of materials on physical parameters of casing.

\section{Water holding capacity (\%)}

Combinations of different casing mixture under the present study showed significant variation in water holding capacity. The, data presented in Table-1, showed that the water holding capacity was increased in all the treatments. The maximum water holding capacity was found in $\mathrm{T}_{7}-\mathrm{FYM}+$ Soil + Sand (2:1:1), representing 95.95 per cent, followed by $\mathrm{T}_{5}-\mathrm{FYM}+$ 
Soil + Ash (2:1:1), representing 92.45 per cent and $\mathrm{T}_{9}-\mathrm{FYM}$ +Sand+ Ash (3:1:1/2), representing 90.25 per cent. The minimum water holding capacity was recorded in $\mathrm{T}_{10}$ Control FYM, representing, 60.10 per cent. It is also cleared that all the casing mixture were statistically significant with respect to water holding capacity. Gierszynski (1974) [8] working with polish peat, sand and clay and concluded that water holding capacity was important character of a good casing medium. Peyvast et al. (2011) ${ }^{[16]}$ reported that the required physical and chemical properties of a good casing should be high porosity and water holding capacity (WHC), 7.2-8.2 $\mathrm{pH}$, low content of soluble inorganic and organic nutrients and free of disease and pests. Singh et al., (2000) [20] used spent compost with $91.7 \%$ water holding capacity and farm yard manure with $191 \%$ water holding capacity but when used in combination of 1:1, 2:1, 1:3 of FYM and spent compost, the WHC was $141 \%, 109 \%, 121 \%$ respectively. Kalberer (1990) ${ }^{[10]}$ also found the relation between decrease in moisture content of casing soil and increase in fruit body weight.
Bulk density $(\%)$

Similarly, different casing mixture showed significant variation on bulk density. The data presented in Table-1, showed that the bulk density was increased in all the treatments. The maximum bulk density was found in $T_{7}-$ FYM + Soil + Sand (2:1:1), representing 65.40 per cent, followed by $\mathrm{T}_{5}-\mathrm{FYM}+$ Soil + Ash (2:1:1), representing 61.25 per cent and $\mathrm{T}_{9}-\mathrm{FYM}+$ Sand + Ash $(3: 1: 1 / 2)$, presented 58.85 per cent. In case of control bulk density was recorded as 33.15 per cent. It is also cleared that all the casing mixture were statistically significant with respect to bulk density. Singh et al., (2000) ${ }^{[20]}$ various casing mixtures with $0.60-0.88$ $\mathrm{g} \mathrm{cm}^{3}$ were used to determine of the bulk density, physicochemical properties of casing materials (Singh, et. al., 2000; Choudhary et al., 2009; Polat et al., 2008.) ${ }^{[20,5,17]}$ According to them, casing sample as farmyard manure (FYM) + spent mushroom substrate (SMS) had minimum bulk density while the casing sample FYM + vermiculite (VC) showed relatively higher bulk density. Bels koning (1950) emphasized the importance of porosity so that proper gaseous exchange could take place. Kurtzman (1995) considered porocity as one of the most important characters of casing medium to get maximum crop yield.

Table 1: Effect of different of casing materials on water holding capacity and Bulk density of casing mixture

\begin{tabular}{|c|c|c|}
\hline Treatment & Water holding Capacity \% & Bulk density Capacity \% \\
\hline 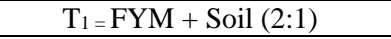 & 84.50 & 54.70 \\
\hline $\mathrm{T}_{2}=\mathrm{FYM}+$ Soil $(1: 1)$ & 82.90 & 51.45 \\
\hline $\mathrm{T}_{3}=\mathrm{FYM}+$ Sand $(2: 1)$ & 73.75 & 42.30 \\
\hline $\mathrm{T}_{4}=\mathrm{FYM}+$ Sand $(1: 1)$ & 68.30 & 37.75 \\
\hline $\mathrm{T}_{5}=\mathrm{FYM}+$ Soil+Ash $(2: 1: 1)$ & 92.45 & 61.25 \\
\hline $\mathrm{T}_{6=} \mathrm{FYM}+$ Sand +Ash $(2: 1: 1)$ & 87.60 & 55.25 \\
\hline $\mathrm{T}_{7}=\mathrm{FYM}+$ Soil + Sand $(2: 1: 1)$ & 95.95 & 65.40 \\
\hline $\mathrm{T}_{8}=\mathrm{FYM}+\operatorname{Ash}(3: 1)$ & 80.95 & 48.60 \\
\hline $\mathrm{T}_{9=} \mathrm{FYM}+$ Sand + Ash $(3: 1: 1 / 2)$ & 90.25 & 58.85 \\
\hline $\mathrm{T}_{10}=$ Control (FYM only) & 60.10 & 33.15 \\
\hline SEm \pm & 1.400 & 0.739 \\
\hline $\mathrm{CD}$ at $5 \%$ & 4.158 & 2.195 \\
\hline
\end{tabular}

Effect of different casing mixture on yield parameters of White button mushroom

\section{Length of stalk $(\mathbf{c m})$}

The casing materials have ability to increase yield and yield parameters like length and diameter of stalk, thickness of pileus etc. of white button mushroom. The data presented in Table- 3 , showed that the length of stalk $(\mathrm{cm})$ was increased in all the treatments. The maximum length of stalk $(\mathrm{cm})$ was found in $\mathrm{T}_{7}-\mathrm{FYM}+$ Soil + Sand (2:1:1), representing 3.04 $\mathrm{cm}$, followed by $\mathrm{T}_{5}-\mathrm{FYM}+$ Soil + Ash $(2: 1: 1)$, as $2.97 \mathrm{~cm}$ and $\mathrm{T}_{9}-\mathrm{FYM}+$ Sand+ Ash $(3: 1: 1 / 2)$, represented $2.94 \mathrm{~cm}$. against $1.69 \mathrm{~cm}$ in case of Control (FYM) $\mathrm{T}_{10}$. From the Table it is also cleared that all the treatments increase length of stalk (cm) over control.

The casing layer influences yield, quality and uniformity of cropping of the button mushroom. Thus, mushroom productivity, size and mass are directly affected by the casing layer. The casing soil is reported to possess certain physical, chemical and microbiological properties having stimulatory role in Agaricus fruiting (Ahlawat 2002) ${ }^{[2]}$. Athar (1986) stated that Pleurotus ostreatus completed spawn running in 17-20 days on different substrates and time for pinheads formation was noted as 23-27 days with variable length of stripe.

\section{Diameter of stalk $(\mathbf{c m})$}

Different casing mixture showed significant variation on diameter of stalk $(\mathrm{cm})$. The data on the diameter of stalk $(\mathrm{cm})$ presented in Table- 2, showed that the diameter of stalk $(\mathrm{cm})$ was increased in all the treatments as compare to control. The maximum diameter of stalk $(\mathrm{cm})$ was found in $\mathrm{T}_{7}-\mathrm{FYM}+$ Soil + Sand $(2: 1: 1)$, representing $2.84 \mathrm{~cm}$, followed by $\mathrm{T}_{5}-$ FYM +Soil + Ash (2:1:1), representing $2.69 \mathrm{~cm}$ and $\mathrm{T}_{9}-\mathrm{FYM}$ + Sand + Ash (3:1:1/2), as $2.59 \mathrm{~cm}$. Among the treatments, the minimum diameter of stalk $(\mathrm{cm})$ was recorded in $\mathrm{T}_{10}$ treatment representing, $2.09 \mathrm{~cm}$. It is also cleared from the table that all the casing mixture was statistically significant with respect to diameter of stalk $(\mathrm{cm})$. Casing material is used in mushroom to cover a nutritional rich composted substrate colonized with mycelium, and has an essential function in stimulating and promoting the development of sporophores (Noble and Pennington 2005) ${ }^{[13]}$. Onokpise et al. (2007) ${ }^{[14]}$ established that palm kernel cake improves the thickness of fruiting bodies of mushroom species. This increase in thickness of the stipe was recorded at maturity in mushrooms grown in variable substrates.

\section{Diameter of Pileus (cm)}

The different casing mixture showed significant variation on diameter of pileus $(\mathrm{cm})$. The data presented in Table-3, showed that the diameter of pileus $(\mathrm{cm})$ was increased in all the treatments. The maximum diameter of pileus $(\mathrm{cm})$ was recorded in $\mathrm{T}_{7}-\mathrm{FYM}+$ Soil + Sand (2:1:1), representing 5.49 $\mathrm{cm}$, against $4.01 \mathrm{~cm}$ in case of control.The $\mathrm{T}_{5}$ treatment- FYM + Soil + Ash (2:1:1), representing the value5.34 cm which is second highest among the treatments. From the table, it is 
cleared that all the treatments, increase the diameter of pileus (cm) over control. It is also cleared that all the casing mixture were statistically significant with respect to diameter of pileus (cm). Similar finding was reported by Ram and Kumar (2010) ${ }^{\text {[18] }}$. Pardo 2004 and Singh et al., (2000) ${ }^{[20]}$ evaluated different casing materials for the cultivation of button mushroom. Jarial and Shandilya (2005) ${ }^{\text {[9] }}$ also proved that municipal waste based vermi compost (HWBV) in combination with other casing materials was evaluated as a casing substrate for $A$. bisporus. Zerihun Tsegaye (2015) found that mixture of cotton waste and coffee pulp yielded the highest total weight and number of fruit bodies and also had a wider pileus diameter.

\section{Thickness of pileus $(\mathrm{cm})$}

The pileus of mushroom was cut with Sharpe knife and thickness of pileus was measure. The data presented in Table3 , showed that the thickness of pileus $(\mathrm{cm})$ with $2.04 \mathrm{~cm}$ was increased in all the treatments. The maximum thickness of pileus $(\mathrm{cm})$ was found in $\mathrm{T}_{7}-\mathrm{FYM}+$ Soil + Sand $(2: 1: 1)$, followed by $\mathrm{T}_{5}-\mathrm{FYM}+$ Soil + Ash $(2: 1: 1)$, treatments 1.89 $\mathrm{cm}$. Among the treatment the minimum Thickness of pileus (cm) was recorded in representing, $1.14 \mathrm{~cm}$. It is also cleared from the table that all the casing mixture were statistically significant with respect to thickness of pileus $(\mathrm{cm})$. The initiation and growth of mushroom sporophores depend not only on the genetic capacity of the mycelium to yield fruit, but also on physical, environmental, chemical, nutritive and microbiological factors (Pardo et al., 2002a, b). Similar result was reported by Dhar et. al., (2006) were used eight commonly available casing materials in India viz, FYM, SMC, CCP, MG, VC, Terracare-A, Terracare-B and FYM+ SMC to identify the suitable casing materials for use in button mushroom cultivation and coir pith result as early pinning and significantly higher number of fruit bodies and total yield. This result also conforms with the findings of Pardo 2004 and Singh et. al., (2000) ${ }^{[20]}$ evaluated different casing materials for the cultivation of button mushroom. Jarial and Shandilya (2005) ${ }^{[9]}$ also proved that municipal waste based vermi compost (HWBV) in combination with other casing materials was evaluated as a casing substrate for A. bisporus. Similar finding was reported by Ram and Kumar (2010) ${ }^{[18]}$.

Table 2: Effect of different casing mixture on yield parameters of White Button mushroom

\begin{tabular}{|c|c|c|c|c|c|c|c|c|}
\hline Treatments & $\begin{array}{c}\text { Length of } \\
\text { stalk (cm) }\end{array}$ & $\begin{array}{c}\text { Increase in stalk } \\
\text { length over } \\
\text { control (\%) }\end{array}$ & $\begin{array}{c}\text { Diameter of } \\
\text { stalk (cm) }\end{array}$ & $\begin{array}{c}\text { Increase in } \\
\text { Diameter of stalk } \\
\text { over control (\%) }\end{array}$ & $\begin{array}{c}\text { Diameter of } \\
\text { Pileus (cm) }\end{array}$ & $\begin{array}{c}\text { Increase in } \\
\text { Diameter of Pileus } \\
\text { over control (\%) }\end{array}$ & $\begin{array}{c}\text { Thickness of } \\
\text { pileus (cm) }\end{array}$ & $\begin{array}{c}\text { Increase in } \\
\text { Thickness of pileus } \\
\text { over control (\%) }\end{array}$ \\
\hline $\mathrm{T}_{1}$ & 2.44 & 44.37 & 2.44 & 16.74 & 4.95 & 15.11 & 1.64 & 43.85 \\
\hline $\mathrm{T}_{2}$ & 2.44 & 44.38 & 2.40 & 14.83 & 4.84 & 12.55 & 1.54 & 35.08 \\
\hline $\mathrm{T}_{3}$ & 2.24 & 32.54 & 2.34 & 11.96 & 4.59 & 6.74 & 1.29 & 13.15 \\
\hline $\mathrm{T}_{4}$ & 2.19 & 29.58 & 2.24 & 7.17 & 4.49 & 4.41 & 1.24 & 8.77 \\
\hline $\mathrm{T}_{5}$ & 2.97 & 75.73 & 2.69 & 28.70 & 5.34 & 24.18 & 1.89 & 65.78 \\
\hline $\mathrm{T}_{6}$ & 2.64 & 56.21 & 2.54 & 21.53 & 5.09 & 18.37 & 1.72 & 50.87 \\
\hline $\mathrm{T}_{7}$ & 3.04 & 79.88 & 2.84 & 35.88 & 5.49 & 27.67 & 2.04 & 78.94 \\
\hline $\mathrm{T}_{8}$ & 2.34 & 38.46 & 2.34 & 11.96 & 4.74 & 10.23 & 1.44 & 26.31 \\
\hline $\mathrm{T}_{9}$ & 2.94 & 65.08 & 2.59 & 23.92 & 5.24 & 21.86 & 1.79 & 57.01 \\
\hline $\mathrm{T}_{10}$ & 1.69 & - & 2.09 & - & 4.01 & - & 1.14 & - \\
\hline $\mathrm{SEm} \pm$ & 0.037 & - & 0.029 & - & 0.090 & - & 0.024 & - \\
\hline $\mathrm{CD}$ at $5 \%$ & 0.109 & - & 0.087 & - & 0.267 & - & 0.072 & - \\
\hline
\end{tabular}

$\mathrm{T}_{1}-\mathrm{FYM}+$ Soil (2:1), $\mathrm{T}_{2}-\mathrm{FYM}+$ Soil (1:1), $\mathrm{T}_{3}-\mathrm{FYM}+$ Sand (2:1) $\mathrm{T}_{4}-\mathrm{FYM}+$ Sand (1:1), $\mathrm{T}_{5}-\mathrm{FYM}+$ Soil+Ash $(2: 1: 1), \mathrm{T}_{6}-$ FYM + Sand + Ash (2:1:1) $\mathrm{T}_{7}-\mathrm{FYM}+$ Soil + Sand (2:1:1), $\mathrm{T}_{8}-\mathrm{FYM}+$ Ash (3:1) $\mathrm{T}_{9}-\mathrm{FYM}+$ Sand+ Ash (3:1:1/2) and T $10-$ Control FYM

\section{Effect of different type of casing mixture on fresh and dry weight of mushroom White button mushroom \\ Fresh weight (g)}

The casing materials have ability to increase the fresh and dry matter on fruiting body of mushroom. The data presented in Table-5, showed that the fresh weight $(\mathrm{g})$ was increased in all the treatments. The maximum fresh weight $(\mathrm{g})$ was recorded in $\mathrm{T}_{7}-\mathrm{FYM}+$ Soil + Sand (2:1:1), representing 1192.41 against $763.89 \mathrm{~g}$ in case of control which is increased by 56.6 per over control. The treatment $\mathrm{T}_{5}-\mathrm{FYM}+$ Soil + Ash (2:1:1), representing $1144.02 \mathrm{~g}$ indicating second highest among the treatments. From the table, it is cleared that different casing mixture showed significant variation of fresh weight of mushroom. It is also cleared that all the casing mixture were statistically significant with respect to fresh weight (g) of mushroom. Sarker and Chowdhury (2013) reported that the concentration level $10 \mathrm{ppm}$ and $20 \mathrm{ppm}$ produced the highest number of effective fruiting body. This similar finding has also been reported by Day et al., (2007). Nirdesh and S. K. Biswas (2019) found that Pleurotus sajor caju was harvested in 5 flushes, the maximum yield was obtained in the first flush, than the second and third flushes in all the treatments. They also found that the maximum yield with $1483 \mathrm{gm}$ per bag was obtained from combination of substrates as 3/4 wheat straw+1/4 mustard straw+100gm wheat bran. Kaur and Atri, (2016) [11] found that the maximum yield was obtained with $\mathrm{GA}_{3}$ when sprayed at pin head formation as comparison to IBA and IAA.

\section{Dry weight $(\mathrm{g})$}

Similarly different casing mixture showed significant variation on dry weight $(\mathrm{g})$ of mushroom. The data presented in Table-5, showed that the dry weight (g) was increased in all the treatments. The maximum dry weight $(\mathrm{g})$ was found in $\mathrm{T}_{7}$ - FYM + Soil + Sand (2:1:1), representing $173.42 \mathrm{~g}$, followed by $\mathrm{T}_{5}-\mathrm{FYM}+$ Soil + Ash (2:1:1), representing $154.3 \mathrm{~g}$ and $\mathrm{T}_{9}$ - FYM + Sand + Ash (3:1:1/2), presented 147.2 g. The minimum dry weight $(\mathrm{g})$ was recorded in $\mathrm{T}_{10}$ - Control FYM, representing, 82.8(g). Ahlawat and Vijay (2000) ${ }^{[4]}$ reported yield stimulary effect of different micro-nutrients and growth hormones on A. bisporus button mushroom. The spray of 0.1 per cent verdix (commercial formulation of Indole butyric acid) resulted in significantly higher mushroom yield at the pinhead initiation state of the first three flushes of the cropping. Xavier and Kumuthakalavalli (2001) reported that application of indole acitic acid (IAA), Gibberallic acid $\left(\mathrm{GA}_{3}\right)$ and kenetin (50 ppm and $100 \mathrm{ppm}$ ) were increased the yield up to 46.8 and 37.8 percentage respectively over the control. 
Table 3: Effect of different type of casing mixture on fresh and dry weight of White button mushroom

\begin{tabular}{|c|c|c|c|c|c|}
\hline Treatment & $\begin{array}{l}\text { Fresh weight } \\
\text { (g) }\end{array}$ & $\begin{array}{l}\text { Percentage increase in fresh weight over } \\
\text { control }\end{array}$ & $\begin{array}{l}\text { Dry weight } \\
(\mathrm{g})\end{array}$ & $\begin{array}{c}\text { Percentage increase in dry weight over } \\
\text { control }\end{array}$ & \\
\hline $\mathrm{T}_{1}$ & 1089.15 & 42.56 & 132.5 & 29.69 & \\
\hline $\mathrm{T}_{2}$ & 1063.46 & 39.19 & 125.75 & 22.51 & \\
\hline $\mathrm{T}_{3}$ & 988.25 & 29.35 & 108.6 & 7.73 & \\
\hline $\mathrm{T}_{4}$ & 871.68 & 14.05 & 96.75 & 4.84 & \\
\hline $\mathrm{T}_{5}$ & 1144.02 & 48.30 & 154.3 & 14.13 & \\
\hline $\mathrm{T}_{6}$ & 1122.36 & 46.90 & 141.15 & 6.70 & \\
\hline $\mathrm{T}_{7}$ & 1192.41 & 56.6 & 173.42 & 8.553 & 133.38 \\
\hline $\mathrm{T}_{8}$ & 1118.77 & 46.43 & 119.4 & 10.00 & 130.82 \\
\hline $\mathrm{T}_{9}$ & 1135.48 & 49.93 & 147.2 & 11.81 & 130.55 \\
\hline $\mathrm{T}_{10}$ & 763.89 & - & 82.8 & - & - \\
\hline SEm \pm & 19.370 & & 2.000 & & \\
\hline \begin{tabular}{|c|}
$\mathrm{CD}$ at $5 \%$ \\
\end{tabular} & 57.544 & & 5.943 & & \\
\hline
\end{tabular}

\section{Reference}

1. Adejumo TO, Awosanya OB. Proximate and mineral composition of four edible mushroom species from South Western Nigeria. African Journal of Biotechnology. 2005; 4(10):1084-1088.

2. Ahlawat OP. Fluctuations in $\mathrm{pH}$ and temperature in the compost and compost casing interface their effect on yield of Agaricus bisporus. Mush. Res. 2002; 11(1):1114.

3. Ahlawat OP, Rai RD. Use of ascorbic acid, Veradix and Agaricus bisporus cultivation - effect on yield, quality and shelf life. Mushroom Research. 1997; 7(1):19-24.

4. Ahlawat OP, Vijay B. Effect of Veradix spraying on yield, yielding pattern and profit in cultivation of Agaricus bitorquis Mushroom Research. 2000; 9(1):3941.

5. Choudhary H, Baysal E, Yigitbasi ON, Colak M, Peker H. Studies on different solid state fermented composts for the mycelial growth of Button mushroom. Transactions of the Asabe. 2009; 49(3):819-82.

6. Colak HE, Baysal H, Simsek H, Toker F, Yilmaz. Cultivation of Agaricus bisporus on wheat straw and waste tea leaves based compost and locally available casing materials Part-3: dry matter, protein and carbohydrate contents of Agaricus bisporus. African J Biotechnol. 2007; 6(24):2855-2859.

7. Dhar BL, Gupta OP, Raj D. Casing layer as related to mushroom yield and quality in Agaricus bisporus in India. Mush. Res. 2006; 15(2):111-123.

8. Gierszynski M. Effect of composition of casing layer on cropping, 1974.

9. Jarial RS, Shandilya TR, Jarial K. Casing in mushroom beds-a review. Agricultural Review. 2005; 26:261-271.

10. Kalberer PP. Influence of water potential of casing soil on crop yield and on dry matter content, osmotic potential and mannitol content of fruit bodies of $A$. bisporus. Journal of Horticulture Science. 1990; 65:573581.

11. Kaur B, Atri NS. Effect of growth regulators and trace elements on the vegetative growth of Pleurotus sapidus QUÃL. International Journal of Pharmacy and Pharmaceutical Sciences. 2016; 8:283-7.

12. Nirdesh Kumar SK, Biswas. J. Mycopathol. Res. (ISSN 0971-3719) Indian Mycological Society, Department of Botany, University of Calcutta, Kolkata 700 019, 2019; 57(1):35-40.

13. Noble R, Pennington AD. Partial substitution of peat in mushroom casing with fine particle coal tailings. Sci. Horti. 2005; 104:351-367.
14. Onokpise O, Abazinge MB. Stabilization and utilization of food processing waste as a slow release of nitrogenous fertilizer for production of cabbage in Florida, USA and mushroom in Ghana, Africa. J Agric. Environ. Sci. 2007; 2:1-6.

15. Pardo A, DE Juan A, Pardo JE. Factores queinfluyen enlainiciación de la fructificación del champiñón cultivado. I. Factores físicos y ambientales. Factores químicos y nutritivos. ITEA. 2002a; 98(1):33-43.

16. Peyvast GH, Shahbodaghi J, Remezani P, Olfati JA. Performance of tea waste as a peat alternative in casing materials for bottom mushroom (Agaricus bisporus (L.) Sing.) cultivation. Biosci. Biotech. Res. Asia. 2011; 4:16.

17. Polat EF, Erler H, Ceyin T. Erdemir. The effect of vegetable materials on the yield and productivity of Agaricus bisporus. Intercienia. 2008; 33(1):776-780.

18. Ram RC, Kumar S. Agricultural wastes used as casing mixtures for production of Button mushroom. Indian J. Sci. Res. 2010; 1(1):21

19. Shandilya TR, Seth PK, Kumar S, Munjal RL. Effect of different spawning methods on productivity of Agaricus bisporus. Indian Journal of Mycology and Plant Pathology. 1974; 4:129-131

20. Singh M, Singh RP, Chaube HS. Impact of physiochemical properties of casing on yield of Agaricus bisporus (Lange) Imbach. (Van. Griensven, ed.) In: Science and cultivation of Edible fungi Balkema, Rotterdam, 2000, 441-446.

21. Zerihun, Tsegaye. Growing of Oyster mushrooms using agricultural residues at Ethiopian biodiversity Institute Addis, 2015. 